\title{
correspondence
}

\section{Megalithic alignments}

SiR,--In your editorial "Science beyond the fringe" (April 12) you speak of archaeology as "plagued by a series of ideas which have achieved a following particularly among the young". The extreme example you give of this is "people busily poring over Ordnance Survey maps of Britain plotting mythical alignments between ancient monuments and erecting fanciful hypotheses about prehistoric technological civilisations." To this, as you say, Professor Glyn Daniel has objected in his Antiquity editorials.

Please allow me, as an author on the subject ridiculed in your editorial, the privilege of a brief comment.

You declare that alignments between ancient monuments are "mythical" and hypotheses about advanced prehistoric civilisations "fanciful", although as editor of a scientific journal you are of course aware that your statement of opinion does not necessarily make them so. It is ironical that the first man to detect significant alignments between megalithic sites was your predecessor, Sir Norman Lockyer, editor of Nature for the first 50 years of its existence. In fact, despite the studied neglect with which Lockyer has been treated by archaeologists throughout this century, his main conclusions, that megalithic sites were inter-related and orientated by astronomical considerations, are now generally accepted, even by the editor of Antiquity, as the result of recent work by Professor Thom and other astro-archaeologists. The quality of criticism brought against Lockyer and his school is typified by the comment with which O. G. S. Crawford, a former editor of Antiquity, dismissed the evidence of A. Watkins relating to the deliberate alignment of ancient sites: that it was "based on a misconception of primitive society." This comment perfectly illustrates the determination of modern archaeologists to prefer the basic historical paradigms they have set up above any evidence that might contradict them.

Personal experience shows that archaeologists, Professor Daniel included, simply refuse to review facts and evidence tending against current orthodoxy. In a book published by Garnstone Press early this year, The Old Stones of Land's End, I demonstrated, in a way that must convince any reasonable person who cares to check the facts, the existence of planned megalithic alignments in West Cornwall. The book attracted a good number of local reviews but not one public comment by any archaeologist. It is therefore rather galling to read your account of archaeologists being "plagued" by theories of the interrelationship of megalithic sites. Would not their best remedy be to attempt a serious refutation of the evidence offered them?

$$
\begin{aligned}
& \text { Your faithfully, } \\
& \text { JOHN MicheLL }
\end{aligned}
$$

11, Miles Buildings,

Bath, Somerset, UK

\section{Call for biohazard legislation}

SIR--Although Brian Ford (Nature August 2) refers to various Acts of Parliament, he makes no mention of the Safety and Health at Work etc. Act which received the Royal Assent on July 31. Clauses 2(2)(b) and 3(1) of the Act place a general duty on employers to protect both their workers and other persons from risks to health in connection with the use, handling, storage and transport of articles and substances; and under Clauses 15 and 16 , the Secretary of State may make Regulations, or the Health and Safety Commission may prepare and issue Codes of Practice (or approve Codes of Practice prepared by others) for any of the general purposes of the Act. I would therefore suggest that no further legislation is necessary and that the way is clear for agreed Codes of Practice to be promulgated to deal with the different groups of organisms, as Brian Ford suggests.

\section{Yours faithfully, J. A. TANnAhill}

Employment Medical Advisory Service, Department of Eirloloyment,

London, UK

\section{Population policy study}

SiR,--I should like to bring to the attention of readers of Nature a survey of the field of reproductive biology and contraceptive development sponsored by the Ford Foundation. The Foundation has asked for an inventory of where we stand in terms of (1) knowledge concerning the reproductive process and fertility control and (2) the human and financial resources that are being brought to bear on the matter of bringing population growth within tolerable limits. For the conduct of this study, a headquarters has been established in Boston with a worldwide network of collaborators and consultants and an international advisory committee drawn from public and private donor agencies, universities and the pharmaceutical industry.

The force that motivated this major study is the accumulating evidence that an inadequate global effort is being waged in this field. The illusion is that the pressure of more immediate biosocial problems supersedes the need to control human fertility. The facts are otherwise.

The survey was initiated in July 1973 and is expected to be completed in 1975 The findings will be published in full on completion of the survey and as interim reports on special topics.

The comments, views and opinions by readers of Nature concerning any or all aspects of this survey will be welcome and helpful in drafting recommendations and guidelines for building on present progress in the understanding of reproductive phenomena and stabilisation of the global populace on a level commensurate with a high quality of life and human dignity.

Yours faithfully, Roy O. GReEP

Laboratory of Human Reproduction and Reproductive Biology, 4.5 Shattuck Street,

Boston, Massachusetts 02115

\section{Astronomical independence}

SIR,-I write to correct John Gribbin who, in discussing (Nature 250, 538, 1974) the thousandth issue of The Observatory, wrongly describes it as the house journal of the Royal Astronomical Society. His mistake is understandable since The Observatory does, by long tradition, report the proceedings of the Society's meetings and is circulated to all Fellows of the Society. It is, however, published by 'The Editors of "The Observatory",' as is clearly stated in each issue, and has no official connection with the Society. The Editors, indeed, fiercely maintain their independence.

Our house journal is The Qiarterly Journal of the Royal Astronomical Society.

Yours faithfully, John Shakeshaft

Royal Astronomical Society, London 